\title{
Nuclear Imaging of Glucose Transport/Metabolism - An Interesting Tool to Screen Insulin Resistance, Refine Diagnosis of Type 2 Diabetes, Understand Disease Mechanisms, and/or Evaluate New Therapies
}

\author{
Perret P., Henri M., Slimani L., Fagret D. and Ghezzi C. \\ UJF-Grenoble 1/INSERM UMR 1039
}

France

\section{Introduction}

Over the past two decades, a striking increase in the number of people with type 2 diabetes has been observed. However, type 2 diabetes may remain undiagnosed for as long as 5 to 7 years before the appearance of clinical symptoms. Insulin resistance (IR) is the best prediction factor of type 2 diabetes (Reaven, 1988; Erikson et al., 1989; Taylor et al., 1994; Henry, 2003). Therefore, early IR detection is of major clinical interest (McLaughlin \& Reaven, 2003). Resistance to insulin-mediated glucose uptake occurs in most insulin sensitive tissues: the skeletal muscle, myocardium and adipose tissue. Mechanisms underlying this defect are still not fully understood (for review Biddinger \& Kahn, 2006; Muoio \& Newgard, 2008; Samuel et al., 2010). Until now, there is no available technique in clinical routine that allows the non-invasive assessment of insulin sensitivity in specific tissues under physiologic or pathophysiologic conditions. This kind of approach is possible using appropriate radiolabelled tracers that can be detected non-invasively.

Indeed, a tracer is a compound that is chemically identical but separately detectable from the tracee, in this case glucose. Injected intravenously, the tracer is present in negligible quantities that do not themselves perturb metabolism, and its distribution in a given organ reflects the appearance or clearance rate of the tracee in this organ.

Radiolabelled glucose analogues have been used for many years (D-glucose, L-glucose, 2deoxyglucose, 3-O-methyl-D-glucose) labelled with carbone 14 or tritium associated with hyperinsulinaemic euglycaemic clamp in animals, even in humans, to understand disease mechanisms and/or evaluate new therapies for type 2 diabetes. Modeling of washout curves of tracers allowed good estimation of glucose inward/outward transport and phosphorylation rates, but the use of these $\beta$ - emitter radioisotopes is not always allowed in humans, moreover this technique does not permit to evaluate the regional location of metabolic events within tissues. In order to be less restrictive, the same approach has been developed in nuclear imaging, where radioactive tracers are injected to assess noninvasively biological processes in vivo. Thus, a couple of tracers have been evaluated in combination with hyperinsulinaemic euglycaemic clamp, such as ${ }^{18} \mathrm{~F}-2$-deoxy-D-glucose for 
glucose metabolism (transport and phosphorylation), the most famous, or ${ }^{11} \mathrm{C}-3-\mathrm{O}-$ methylglucose for glucose transport evaluation. Experimentally, with the recent development of nuclear imaging cameras with high resolution dedicated to small animals, and the increase of FDG disponibility, a couple of protocoles have been proposed to evaluate glucose uptake in vivo in rat and even in mice. But the necessity of the hyperinsulinaemic clamp conditions, which consist in a 3 hours perfusion of insulin and glucose, rendered this technique complicated and cumbersome for the patient and it cannot be used routinely. More recently, a new tracer, 123I-6-iodo-6-deoxy-D-glucose has been proposed to evaluate insulin-stimulated glucose transport in vivo using a more simple and shorter protocole (Briat et al., 2007).

\section{2. ${ }^{18}$ F-2-deoxy-D-glucose (FDG)}

The most widely used glucose analogue radiotracer in humans is $18 \mathrm{~F}-2$-deoxy-D-glucose (FDG), developed for positron emission tomography (PET) imaging. FDG, a glucose analogue quite similar to 2-Deoxy-Glucose (2DG), is recognized and transported into the cells by glucose transporters, and phosphorylated by hexokinase to form 18F-FDG-6phosphate (Bessell et al., 1972, 1973; Gallagher et al., 1977,1978). It cannot act as a substrate for further glycolysis and so rapidly accumulates in cells that have increased activity of hexokinase and increased glucose transporter levels, such as tumour cells. That is the reason why FDG is extensively used for PET imaging in oncology and has been evaluated and established in clinical routine for initial staging and assessment of response to cancer therapy.

Since glucose transport defect in skeletal muscle is the main characteristic of insulin resistance, FDG and dynamic PET have also been developped to provide tissue-specific metabolic assessment of proximal steps of glucose metabolism in clinical investigations.

We often heard about round trips between bench and bedside, the development of FDG is a perfect example. First, animal studies to assess in vivo insulin resistance in tissues such as skeletal muscle were performed during hyperinsulinaemic clamp with an injection of ${ }^{14} \mathrm{C}$ 2DG, dissection of tissues, and extraction of 2DG-6-P to count carbon 14. Ex vivo or in vitro, this tracer was so usefull in so many fields (i.e. diabetology, oncology, neurology, cardiology...) that an analogue usable in humans was extensively searched for many years. When ${ }^{18}$ FDG was obtained, PET imaging was not widely available. Nowadays with the increasing interest of this tracer in oncology, more and more medical centers are equiped with PET cameras and FDG is becoming more available and less expensive. Then PET cameras dedicated to small animals were developed and experimental studies can be performed.

To assess global insulin sensitivity, the hyperinsulinaemic euglycaemic clamp is the gold standard (DeFronzo et al., 1981). To evaluate insulin stimulated glucose uptake in vivo within individual tissues, the used of 2-[14C]-DG injected as a bolus at the end of the insulin clamp, during steady state, has been developed first in concious rats by Kraegen and colleagues (Kraegen et al.,1983), and since then largely used, even in concious mice (Rossetti et al., 1997). Using this technique, tissue glucose metabolic rate or $\mathrm{Rg}^{\prime}$ can be assessed using plasma kinetic of 2DG over 45 minutes and tissue accumulation of 2-DG-6$\mathrm{P}$ at that time. The main limitation of this technique is the labelling of 2DG with carbon 14, a low energy $\beta$-emitter, which involves the death of the animal, dissection of the tissue and a laborious preparation to count the radioactivity. This method involves also 
numerous blood samples which can represent another limitation especially in mice. FDG, labelled with a $\beta+$ emitter, can be detectable non invasively. This tracer is an analogue of 2DG, i.e. it enters the cell using the same transporter as glucose and once inside the cell FDG is phosphorylated. The kinetics of its uptake reflect both the transport and phosphorylation steps. In human, FDG was first used to evaluate glucose metabolism in brain using dynamic PET-imaging associated with compartimental modeling developped by Sokoloff and colleagues (Sokoloff et al., 1977). This method was afterwards adapted to heart and skeletal muscle, associated with hyperinsulinaemic euglycaemic clamp (Phelps et al., 1978; Nuutila et al., 1992). A tree-compartment model was applied to estimate inward transport, outward transport and phosphorylation rates. Nuutila and colleagues used this technique to demonstrate that the glucose-FFA cycle operates in vivo in both heart and skeletal muscles in humans (Nuutila et al., 1992). In the same manner, Selberg and colleagues showed that patients with liver cirrhosis presented significant insulin resistance, and kinetic constants using the three-compartment model indicated reduced glucose transport in skeletal muscle but unchanged phosphorylation of glucose (Selberg et al., 1993). Another interesting study concerned the evaluation of regional insulin resistance in lean, obese, and obese with type 2 diabetic patients (Kelley et al., 1996). Kelley and colleagues showed that during a hyperinsulinaemic clamp associated with FDG-PET-imaging of skeletal muscle, the rate constant for glucose phosphorylation was similar in obese and lean subjects but reduced in diabetic patients. These in vivo assessment, associated with an immunohistochemical study of GLUT 4 performed ex vivo in muscle biopsies of patients indicated that impaired glucose transport plays a key role in insulin resistance of diabetes and obesity, and that an additional impairment of glucose phosphorylation is evident in the insulin resistance of type 2 diabetes (Kelley et al., 1996) (Figure 1).

First experimental studies with FDG were performed in rabbits hindlimb that was secured between a single pair of coincidence gamma photon detectors positioned on the medial and lateral sides of the posterior thigh (Mossberg et al., 1989). The counting system consisted of two bismuth germanate oxide crystals interfaced to photomultiplier tubes. After signal amplification and filtering by discriminator units, the processed signals from each detector were sent to a coincidence logic unit. Animal has to be anesthetized, and FDG was injected as a bolus and then infused continuously through the experiment. Mossberg and colleagues used the method of graphical analysis of tissue and plasma radioactivity concentrations derived from Patlak and colleagues (Patlak \& Blasberg, 1985) to quantitate the fractional rate of tracer phosphorylation. Briefly, the slope of the relationship between the integral of the plasma radioactivity concentration and the tissue radioactivity concentration during any given time interval yields the transfer constant, $\mathrm{K}$, or the fractional rate of FDG phosphorylation. Multiplication of $\mathrm{K}$ by the plasma glucose concentration gives an index of the rate of glucose uptake $\left(\mathrm{Rg}^{\prime}\right)$. During perturbation by electrical stimulation, an increased in the rate of tracer phosphorylation was observed, but no change of $\mathrm{K}$ was observed during hyperinsulinemia induced by a bolus of insulin. The next step was to introduced the hyperinsulinaemic clamp conditions in the method (Mossberg \& Taegtmeyer, 1991, 1992). But the detection system was developed only by Mossberg and colleagues, and until the development of the first PET-cameras dedicated to small animals available on the market (2002 for Siemens Concorde R4), tissue insulin resistance was assessed with FDG mostly in humans. 

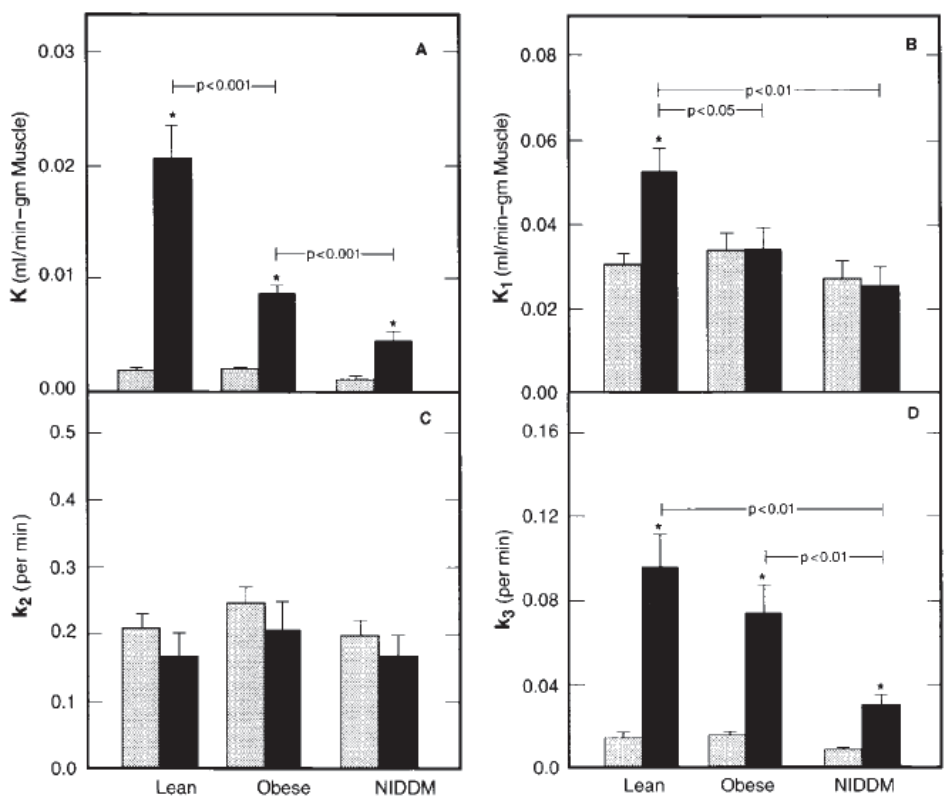

Fig. 1. Glucose transport and phosphorylation rates assessed with ${ }^{18 F D G}$ imaging and mathematical modeling in human skeletal muscle. In $A$, data from lean and obese nondiabetic and obese type 2 diabetic subjects during basal (shaded bars) and insulin stimulated (solid bars) conditions are shown for ${ }^{18} \mathrm{FDG}$ clearance $(\mathrm{K})$ into midthigh muscle; in $B$, the rate constant for transport of ${ }^{18} \mathrm{FDG}\left(\mathrm{K}_{1}\right)$ is shown; in $C$, the rate constant for outward transport $\left(\mathrm{k}_{2}\right)$ of ${ }^{18} \mathrm{FDG}$ is shown; and in $D$, the rate constant for ${ }^{18}$ FDG phosphorylation $\left(\mathrm{k}_{3}\right)$ during basal and insulin-stimulated conditions is shown. *Significant within-group difference comparing basal and insulin-stimulated values $(P<0.05)$. [Figure from Kelley et al, 1996 with permission].

Paternostro and colleagues studied insulin resistance in patients with a history of myocardial infarction (Paternostro et al., 1996). Using PET imaging technique, they measured heart and skeletal muscle blood flow with $\mathrm{H}_{2}{ }^{15} \mathrm{O}$ and glucose uptake with FDG during euglycaemic hyperinsulinaemic clamp. The authors showed that in these patients, insulin resistance affects both the myocardium and skeletal muscle and is independent of blood flow. Numerous studies have been then performed to measure regional insulin resistance, mainly in heart and skeletal muscle in various patients, type 1 or type 2 diabetic (vom Dahl et al., 1993; Voipio-Pulkki et al., 1993), with or without hypertension (Yokoyama et al., 1998), obese or non obese (Kelley et al., 1999), with or without hypertriglyceridemia (Kobayakawa et al., 1999). The technique was also usefull to evaluate the impact of new therapy. For example, Yokoyama and colleagues showed that troglitazone, one of the first available thiazolidinedione, could improve whole-body insulin resistance through the improvement of skeletal muscle glucose uptake but not through a decline in plasma free fatty acid concentration in patients with type 2 diabetes (Yokoyama et al., 2001).

In a way to simplify the technique, the activity in left ventricule or in aorta can be used as arterial input function (Iozzo et al., 2003 ; Keiding et al., 2000). Yokoyama and colleagues 
proposed a even simpler method using static instead of dynamic imaging (Yokoyama et al., 2003).

The advent of small-animal PET technology allowed for the consecutive measurements of biochemical and physiological function in rodents. Sharp and colleagues provided an example of a cardiac imaging study using four radiotracers $\left({ }^{15} \mathrm{O}\right.$-water, 1 - $\left[{ }^{11} \mathrm{C}\right]$-acetate, 1 -

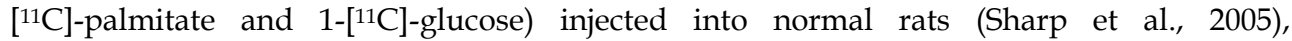
demonstrating that rats can be used for multiple non invasive imaging studies with reproducible results over time with minimal or no change in hemodynamic or substrate levels. Using the same method, Welch and colleagues studied Zucker diabetic fatty (ZDF) rats showed that non invasive measurements of myocardial substrate metabolism were consistent with the expected early metabolic abnormalities that occur in this model of type 2 diabetes mellitus (Welch et al., 2006). To summarize, when compared with their lean controls, the ZDF rat showed (a) elevated insulin, glucose, and FFA levels; (b) elevated FFA utilization and oxidation; (c) preserved myocardial glucose utilization; and (d) a trend toward a lower MVO2. However, the micro-blood sampling technique is necessary to provide accurate blood input function measurements, and when multiple tracer studies are performed in the same animal, this technique is limited by the number of blood samples that can be withdrawn in small animals. Kim and colleagues proposed a factor analysis (FA) technique for extracting the blood input function and myocardial time-activity curve from dynamic small-animal PET images of the rodent heart (Kim et al., 2006). Indeed, CT scans were not available on PET cameras dedicated to small animals at that time rendering the design of ROI in left ventricule rather difficult. The FA method has been used to decompose dynamic images into component images and to determine their time-activity curves by analysis of the variance in the data (Barber, 1980). It has been reported that the FA method successfully extracts the input functions and myocardial time-activity curves from dynamic PET images of canines, humans, and monkeys (Wu et al., 1995 ; 1996). In rat and mice, the FA method enables reliable quantification of physiologic or biologic information generated in small-animal PET-FDG studies and does not require the drawing of ROIs on small structures, such as a rodent heart or other small organs of interest, or repeated blood sampling (Kim et al., 2006). Using small-animal PET, Shogi and colleagues confirmed alterations in myocardial glucose utilization and validated PET measurement of Muscle Glucose Uptake (MGU) against gene and protein expression of GLUTs in the heart of an animal model of type 2 diabetes (Shogi et al., 2008). A new method has been validated in mice, a hybrid image and blood sampling (HIBS) method to derive the input function for quantification of microPET mice data. The HIBS algorithm derives the peak of the input function from the image (on the heart), which is corrected for recovery, while the tail is derived from 5 to 6 optimally placed blood sampling points (Shogi et al., 2007). The method is now well established in rodents, and can be used for example to validate new animal model of type 2 diabetes induced by diet closer to the human disease than genetic animal model available (Ménard et al., 2010).

The compartmental model developed for FDG-PET imaging in skeletal muscle was initially used for PET data acquired in the central nervous system (CNS) and later modified. Bertoldo and colleagues proposed a muscle specific compartmental model, a modification that takes into account movement of FDG from plasma to interstitial space and from interstitial space into tissue via transmembrane glucose transport, as well as an irreversible compartment for formation of FDG-6-P (Bertoldo et al, 2001). Compared with the classic 
model, the skeletal muscle-specific model reveals a more clearly defined effect of insulin on transmembrane glucose transport and an impairment of this response in obesity (Williams et al., 2003).

Resistance to insulin also occurs in adipose tissue. But methods available to study directly adipose tissue metabolism in vivo are limited in human beings and its investigation has been carried out mainly by indirect measurements in the whole body or in cannulated limbs. FDG-PET has been combined with microdialysis to investigate adipose tissue glucose metabolism in human during insulin stimulation. Using this method, Virtanen and colleagues confirmed that obese patients had insulin resistance in both adipose tissue and skeletal muscle (Virtanen et al., 2001).

More recently, Hirvonen and colleagues studied in humans the effects of insulin on brain glucose metabolism and cerebral blood flow in patients with impaired glucose tolerance and healthy subjects using FDG-PET associated to hyperinsulinemic clamp (Hirvonen et al., 2011). Their results suggest that insulin stimulation of brain glucose metabolism is maximal at fasting concentrations in healthy subjects but not in patients with impaired glucose tolerance. This study showed that it could be a very usefull technique to evaluate the role of insulin in the brain and the possible insulin resistance in some conditions of this organ which has been for a long time considered as a non insulin sensitive tissue.

\section{3-O-methyl-D-glucose (3-OMG)}

Skeletal muscle glucose uptake requires delivery of glucose to the sarcolemma, transport across this membrane, and the irreversible phosphorylation of glucose by hexokinase inside the cell. Because these three processes are so tightly coupled, it is difficult to determine the role of each of these steps in controlling the rate of muscle glucose uptake in vivo. An alternative approach is the measurement of the steady-state distribution of a non metabolizable glucose analogue across the sarcolemma, which allows the calculation of the transsarcolemmal glucose gradient. Numerous in vitro and in vivo experiments have shown that 3-O-methyl-D-glucose (3-OMG) is an ideal glucose analogue to probe transmembrane transport, sharing the same transport system as glucose and with equivalent affinity for glucose transport proteins (Narahara \& Ozand, 1963; Buschiazzo et al., 1970; Carruthers, 1990; O’Doherty et al., 1998).

Cobelli and colleagues have used the perfused forearm and euglycaemic hyperinsulinaemic clamp techniques in combination with a dual-tracer injection to measure basal and insulinmediated glucose transport in normal subjects. L- $\left[{ }^{3} \mathrm{H}\right]$ glucose, which is not transported, was used to trace extracellular glucose kinetics, and 3-O-[14C]-methyl-D-glucose was used to monitor glucose transport across the cell membrane (Cobelli et al., 1989). A linear compartmental model was developed that accounts for blood flow heterogeneity. Using the same method, Bonadonna and colleagues have shown that transmembrane glucose transport was insulin resistant in the skeletal muscle of patients with type 2 diabetes and that this impairment was proportional to their degree of insulin resistance (Bonadonna et al., 1993). Halseth and colleagues adapted the technique for rat studies and showed that during exercice glucose phosphorylation becomes an important limitation to skeletal muscle (soleus) glucose uptake. During hyperinsulinaemia, both glucose delivery and glucose phosphorylation influence the rate of skeletal muscle glucose uptake more than under basal conditions (Halseth et al., 1998). The same group studied high fat diet rats showing a defect in skeletal muscle glucose transport under insulin conditions (Halseth et al., 2000), and the influence of muscle 
fiber types on the rate of insulin-stimulated muscle glucose uptake, with glucose delivery and transport being the primary limiting factors in type II muscle (Halseth et al., 2001; Petersen et al., 2003). Recently, in vivo rates of transmembrane glucose transport and intracellular glucose phosphorylation were determined by analyzing the dilution curves of D-mannitol, [ $\left.{ }^{14} \mathrm{C}\right] 3 \mathrm{OMG}$, and D-[3- $\left.{ }^{3} \mathrm{H}\right]$ glucose, using a multicompartmental model of glucose kinetics in forearm tissues (Pendergrass et al., 2007). The authors concluded that 1) obese non diabetic, lean type 2 diabetic, and offspring manifest moderate-to severe muscle insulin resistance and decreased insulinstimulated glucose transport and glucose phosphorylation in forearm muscle; these defects in insulin action are not further reduced by the combination of obesity plus diabetes; and 2) the increase in intracelullar glucose concentration under hyperinsulinaemic euglycaemic conditions in obese and type 2 diabetic groups suggests that the defect in glucose phosphorylation exceeds the defect in glucose transport (Pendergrass et al., 2007).

Concerning imaging studies, the fact that emission from ${ }^{18} \mathrm{~F}$ can occur at either [18F]FDG or [18F]FDG-6-P, creates implicit uncertainty as to whether compartmental modeling achieves separate estimations of glucose transport and phosphorylation. Therefore dynamic PET imaging to isolate the step of transmembrane glucose transport in skeletal muscle based on chemical specificity of 3-OMG labeled with ${ }^{11} \mathrm{C}$ has been proposed (Bertoldo et al., 2005). High quality imaging can be obtained and a clear effect of insulin to modulate the amplitude and configuration of tissue tracer activity was observed. Initial application indicated a robust effect of insulin to stimulate glucose transport in skeletal muscle of lean, healthy, insulin-sensitive volunteers (Bertoldo et al., 2005). Using the same method, Pencek and colleagues showed that in healthy volunteers there was robust dose-responsive insulin stimulation of glucose transport in skeletal muscle (Pencek et al., 2006) (Figure 2).
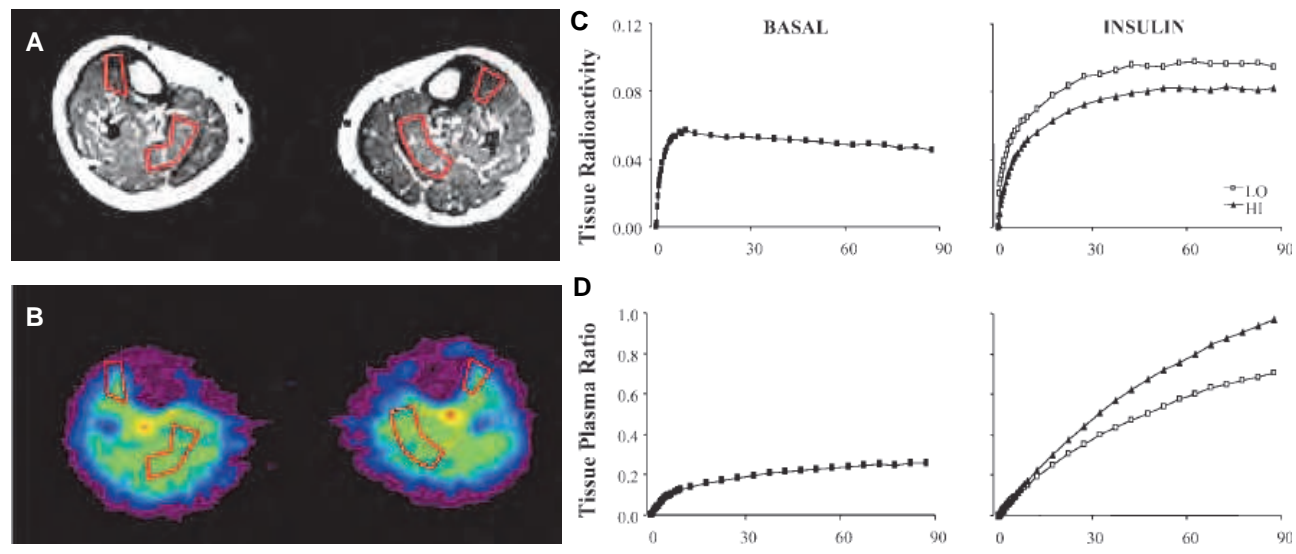

Time (min)

Fig. 2. Glucose transport assessment with ${ }^{11} \mathrm{C}-3-\mathrm{OMG}$ in human skeletal muscle. MRI (A) and PET (B) images were carefully co-registered, and regions of interest (ROIs) were drawn within tibialis anterior and soleus muscle groups. ROIs were then applied to PET images to determine radioactivity accumulation within specific muscle groups. C: representative tissue activity curves during Basal (left), low-insulin (LO), and high-insulin (HI) conditions (right). D: representative tissue to plasma ratios (TPR) of ${ }^{11} \mathrm{C}-3-\mathrm{OMG}$ radioactivity. [Figure adapted from Pencek et al, 2006 with permission]. 
There have been prior in vivo PET investigations in humans using [11C]3-OMG to study glucose transport across the blood-brain barrier (Vyska et al., 1985; Feinendegen et al., 1986; Brooks et al., 1986a, 1986b). But the use of this tracer was limited by the fact that it is labelled with carbon 11, a short half-life radioisotope $\left(t_{1 / 2}=20\right.$ minutes) produced by cyclotron, which undoubtedly explains why very few studies have been devoted to this compound.

\section{4. $\left[{ }^{123} \mathrm{I}\right]-6$-deoxy-6-iodo-D-glucose (6DIG)}

Given the significant interest of a tracer to estimate alterations of glucose uptake in vivo, numerous researchers have tried for many years to develop glucose molecules labelled with a radioactive atom which is a pure $\gamma$-emitter, such as iodine 123, and which could be used routinely in Single Photon Emission Computed Tomography (SPECT), in all Nuclear Medicine centers (Kloster et al., 1983a, 1983b; Goodman et al., 1981a, 1981b; Lutz et al., 1991; Magata et al., 1992; Koumanov et al., 1997a, 1997b; Perret et al, 2004). [123I]-6-deoxy6-iodo-D-glucose (6DIG) was first synthetized by Wassenar and colleagues, but the biological evaluation was limited to tumor uptake and not evaluated further (Wassenaar et al., 1973). The synthesis of 6DIG has been performed again more recently, and its biological behavior was carrefully evaluated. It was similar to that of 3-OMG (Henry et al., 1997a). It is transported into the cell by glucose transporters, but is not phosphorylated or further metabolized and is then free to leave the cell using the same transporters. The cellular uptake of this tracer allows true transport rates to be measured. Moreover, an in vitro study on the adipocytes of diabetic rats and obese mice showed that 6DIG, like 3OMG, could be used to determine alterations in glucose transport (Henry et al., 1997b). Our group then proposed to use 6DIG in vivo to assess insulin resistance by nuclear imaging. Studies in diabetic mice $d b / d b$ and in insulin resistant fructose-fed rats showed that 6DIG was able to assess glucose transport defects in vivo (Slimani et al., 2002; Perret et al., 2003, 2007). In a preliminary study, we have shown in different rat models of insulin resistance that 6 DIG could be used to assess non-invasively, using nuclear NaI probes, different degrees of cardiac insulin resistance without using hyperinsulinaemic clamp (Briat et al., 2007) (Figure 3). Based on these preliminary works, we further investigated the non-invasive assessment of cardiac and skeletal muscle insulin resistance using a gamma camera dedicated to small animals. We validated a simple protocol which is currently undergoing a clinical trial.

\section{Conclusion}

Nuclear imaging is routinely used to refine diagnosis in oncology and cardiology, but although his great potential not yet in diabetology. Probably because all the methods proposed until now were associated with complex protocoles. With the recent development of cameras for small animals, the development of new tracers is rendering easier and then can be proposed for new clinical insights, or experimentally for new drug testing or physiopathology studies. Considering the complexity of mechanisms involved in insulin resistance development, such tools, giving non invasivelly fonctionnal informations in vivo are of great interest. 


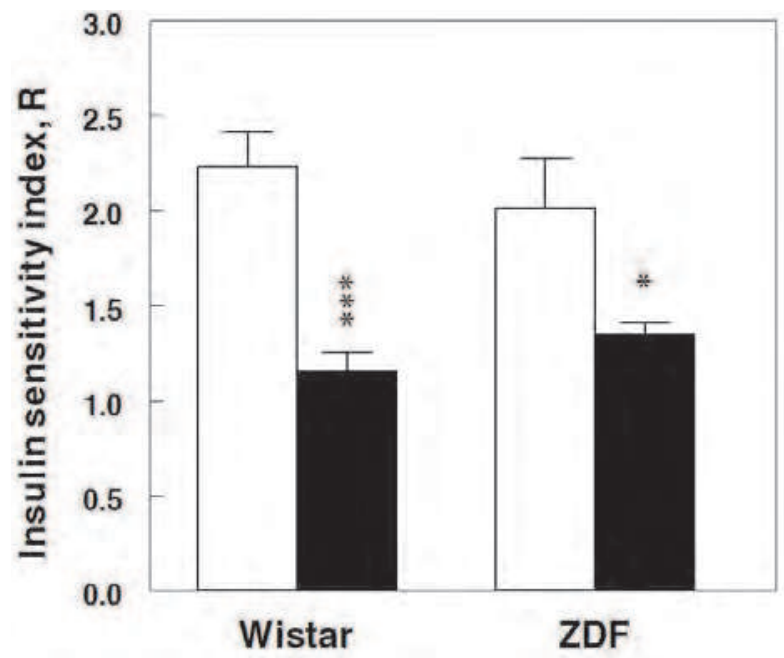

Fig. 3. Index of insulin sensitivity calculated as the ratio of 6DIG transport rate constant in insulin and basal conditions in rat myocardium ( $k_{\text {in }}$ insulin / $k_{\text {in }}$ basal). White bars represent control animals (Wistar and lean ZDF rats) and solid bars insulin resistant animals (fructosefed Wistar and Zucker Diabetic Fatty rats). ${ }^{*}$ Comparison of insulin-resistant rats versus control rats, Mann-Whitney test: ${ }^{*} P<0.05,{ }^{* * *} P<0.001$. [Unpublished figure from the Ghezzi laboratory].

\section{References}

Barber, D.C. (1980). Physics in Medicine and Biology. Vol.25, pp. 283-292.

Bertoldo, A.; Peltoniemi, P.; Oikonen, V.; Knuuti, J.; Nuutila, P. \& Cobelli, C. (2001). American Journal of Physiology. Vol.281, pp. E524-E536.

Bertoldo, A.; Price, J.; Mathis, C.; Mason, S.; Holt, D.; Kelley, C.; Cobelli, C. \& Kelley, D.E. (2005). Journal of Clinical Endocrinology and Metabolism. Vol.90, pp. 1752-1759.

Bessell, E.M.; Foster, A.B. \& Westwood, J.H. (1972). Biochemistry Journal. Vol.128, No.2 (June), pp. 199-204.

Bessell, E.M. \& Thomas, P. (1973). Biochemistry Journal. Vol.131, No.1(January), pp. 83-89.

Biddinger S.B. \& Kahn, R.C. (2006) Annual Review of Physiology. Vol.68, pp. 123-158.

Bonadonna, R.-C.; Del Prato, S.; Saccomani, M.-P.; Bonora, E.; Gulli, G.; Ferrannini, E.; Bier, D.; Cobelli, C. \& DeFronzo, R.A. (1993). Journal of Clinical Investigation. Vol.92, pp. 486-494.

Briat, A.; Slimani, L.; Perret, P.; Villemain, D.; Halimi, S.; Demongeot, J.; Fagret, D. \& Ghezzi, C. (2007). European Journal of Nuclear Medicine and Molecular Imaging. Vol.34, No.11, pp. 1756-1764.

Brooks, D.; Beaney, R.; Lammertsma, A.; Herold, S.; Turton, D.; Luthra, S.; Frackowiak, R.; Thomas, D.; Marshall, J. \& Jones, T. (1986a). Journal of Cerebral Blood Flow and Metabolism. Vol.6, pp. 230-239.

Brooks, D.; Gibbs, J.; Sharp, P.; Herold, S.; Turton, D.; Luthra, S.; Kohner, E.; Bloom, S. \& Jones, T. (1986b) Journal of Cerebral Blood Flow and Metabolism. Vol.6, pp. 240-244. 
Buschiazzo, P.; Terrell, E. \& Regen, D. (1970). American Journal of Physiology. Vol.219, pp. 1505-1513.

Carruthers, A. (1990). Physiological Reviews. Vol.70, pp. 1135-1176.

Cobelli, C, Saccomani, MP, Ferrannini, E, Defronzo, RA, Gelfand, R, Bonadonna, R. (1989). American Journal of Physiology, Endocrinology and Metabolism. Vol.257, No.6 (December), pp. E943-E958.

DeFronzo, R.A.; Jacot, E.; Jequier, E.; Maeder, E.; Wahren, J. \& Felber, J.P. (1981). Diabetes. Vol.30, pp. 1000-1007.

Eriksson, J.; Franssila-Kallunki, A.; Ekstrand, A.; Saloranta, C.; Widén, E.; Schalin, C. \& Groop, L. (1989). New England Journal of Medicine. Vol.321, pp. 337-343.

Feinendegen, L.E.; Herzog, H.; Wieler, H.; Patton, D.D. \& Schmid, A. (1986). Journal of Nuclear Medicine. Vol.27, No. 12 (December), pp. 1867-1877.

Gallagher BM, Ansari A, Atkins H, Casella V, Christman DR, Fowler JS, Ido T, MacGregor RR, Som P, Wan CN, Wolf AP, Kuhl DE, Reivich M. (1977). Journal of Nuclear Medicine. Vol.18, No.10 (October), pp. 990-996.

Gallagher BM, Fowler JS, Gutterson NI, MacGregor RR, Wan CN, Wolf AP. (1978). Journal of Nuclear Medicine. Vol.19, No.10 (October), pp. 1154-1161.

Goodman, M.M.; Kabalka, G.W.; Waterhouse, R.N. \& Daniel, G.B. (1991a). Journal of Labelled Compounds and Radiopharmaceuticals. Vol.30, pp. 278-279.

Goodman, M.M.; Kabalka, G.W.; Meng, X. (1991b). Journal of Labelled Compounds and Radiopharmaceuticals. Vol.30, pp. 280-282.

Halseth, A.E.; Bracy, D.P. \& Wasserman, D.H. (1998). Journal of Applied Physiology. Dec;Vol.85, No.6 (december), pp. 2305-2313.

Halseth, A.E.; Bracy, D.P. \& Wasserman, D.H. (2000) American Journal of Physiology, Endocrinology and Metabolism. Vol.279, No.5 (November), pp. E1064-1071.

Halseth, A.E.; Bracy, D.P. \& Wasserman, D.H. (2001). American Journal of Physiology, Endocrinology and Metabolism. Vol.280, No.6 (June), pp. E994-999.

Henry, C.; Koumanov, F.; Ghezzi, C.; Morin, C.; Mathieu, J.-P.; Vidal, M.; de Leiris, J. \& Comet, M. (1997a). Nuclear Medicine and Biology. Vol.24, pp. 527-534.

Henry, C.; Tanti, J.F.; Grémeaux, T.; Morin, C.; Van Obberghen, E.; Comet, M. \& Le Marchand-Brustel, Y. (1997b). Nuclear Medicine and Biology. Vol.24, No.1 (January), pp. 99-104.

Henry, R.R. (2003). Clinical Therapeutics. Vol.25, suppl.B, pp. B47-B63.

Hirvonen, J.; Virtanen, K.A.; Nummenmaa, L.; Hannukainen, J.C.; Honka, M.-J.; Bucci, M.; Nesterov, S.V.; Parkkola, R.; Rinne, J.; Iozzo, P. \& Nuutila, P. (2011). Diabetes. Vol.60, pp. 443-447.

Iozzo, P.; Geisler, F.; Oikonen, V.; Maki, M.; Takala, T.; Solin, O.; Ferrannini, E.; Knuuti, J. \& Nuutila, P. (2003). Journal of Nuclear Medicine. Vol.44, No.5 (May), pp. 682-689.

Israel, O; Weiler-Sagie, M; Rispler, S; Bar-Shalom, R; Frenkel, A; Keidar, Z; Bar-Shalev, A \& Strauss, HW. (2007). Journal of Nuclear Medicine, Vol.48, pp. 234-239.

Kelley, D.E.; Mintun, M.A.; Watkins, S.C.; Simoneau, J.-A.; Jadali, F.; Fredrickson, A.; Beattie, J. \& Thériault, R. (1996). Journal of Clinical Investigation. Vol.97, pp. 2705-2713.

Kelley, D.E.; Williams, K.V.; Price, J.C. \& Goodpaster, B. (1999). Journal of Nuclear Medicine. Vol.40, No.11 (November), pp. 1798-1804.

Keiding, S.; Munk, O.L.; Schiøtt, K.M. \& Hansen, S.B. (2000). European Journal of Nuclear Medicine. Vol.27, No.4 (April), pp. 407-412.

Kim, J.; Herrero, P.; Sharp, T.; Laforest, R.; Rowland, D.J.; Tai, Y.-C.; Lewis, J.S. \& Welch, M.J. (2006). Journal of Nuclear Medicine. Vol.47, pp. 330-336. 
Kloster, G.; Laufer, P.; Wutz, W.; \& Stocklin, G. (1983a). European Journal of Nuclear Medicine. Vol.8, pp. 237-241.

Kloster, G.; Laufer, P. \& Stocklin, G. (1983b). Journal of Labelled Compounds and Radiopharmaceuticals. Vol.20, pp. 391-415.

Kobayakawa, N.; Aoyagi, T.; Sugiura, S.; Ohtomo, K.; Sasaki, Y.; Omata, M. \& Yazaki, Y. (1999). Journal of Nuclear Medicine. Vol.40, No.7 (July), pp. 1116-1121.

Koumanov, F.; Henry, C.; Ghezzi, C.; Bignan, G.; Morin, C.; Mathieu, J.-P.; Hamant, S.; Vidal, M.; de Leiris, J. \& Comet, M. (1996). Nuclear Medicine and Biology. Vol.23, pp. 53-60.

Koumanov, F.; Henry, C.; Ghezzi, C.; Mathieu, J.-P.; Morin, C.; Vidal, M.; de Leiris, J. \& Comet, M. (1997b). Nuclear Medicine and Biology. Vol.24, pp. 519-525.

Kraegen, E.W.; James, D.E.; Bennett, S.P. \& Chisholm, D.J. (1983). American Journal of Physiology. Vol.245, No.1 (July), pp. E1-7.

Lutz, T.; Dougan, H.; Rihela, T.; Hudon, M.; Cohen, P.; Jamieson, W.R.E. \& Lyster, D.M. (1991). Journal of Labelled Compounds and Radiopharmaceuticals. Vol.29, pp. 535-545.

Magata, Y.; Saji, H.; Ohmomo, Y.; Tanaka, C.; Konishi, J. \& Yokoyama, A. (1992). Journal of Labelled Compounds and Radiopharmaceuticals. Vol.31, pp. 317-328.

McLaughlin, T.L. \& Reaven, G.M. (2003). American Journal of Medicine. Vol.114, pp. 501-502.

Ménard, S.L.; Croteau, E.; Sarrhini, O.; Gélinas, R.; Brassard, P.; Ouellet, R.; Bentourkia, M.; van Lier, J.E.; Des Rosiers, C.; Lecomte, R. \& Carpentier, A.C. (2010). American Journal of Physiology: Endocrinology and Metabolism. Vol.298, pp. E1049-E1057.

Mossberg, K.A. \& Taegtmeyer, H. (1991) Metabolism. Vol.40, No.6 (June), pp. 594-599.

Mossberg, K.A. \& Taegtmeyer, H. (1992). Journal of Nuclear Medicine. Vol.33, No.8 (August), pp. 1523-1529.

Mossberg, K. A., Rowe, R. W., Tewson, T. J. \& Taegtmeyer, H. (1989). Journal of Applied Physiology. Vol.67, No.4, pp. 1569-1577.

Muoio, D.M. \& Newgard, C.B. (2008). Nature reviews: molecular cell biology. Vol. 9 (March), pp. 193-205.

Narahara, H. \& Ozand, P. (1963). Journal of Biological Chemistry. Vol.238, pp. 40-49.

Nuutila, P.; Koivisto, V.A.; Knuuti, J.; Ruotsalainen, U.; Teräs, M.; Haaparanta, M.; Bergman, J.; Solin, O.; Voipio-Pulkki LM, Wegelius, U. \& Yki-Järvinen, H. (1992). Journal of Clinical Investigation. Vol.89, No.6 (June), pp. 1767-1774.

O'Doherty, R.; Halseth, A.; Granner, D.; Bracy, D. \& Wasserman, D. (1998). American Journal of Physiology. Vol.274, pp. E287-E296.

Paternostro, G.; Camici, P.G.; Lammerstma, A.A.; Marinho, N.; Baliga, R.R.; Kooner, J.S.; Radda, G.K. \& Ferrannini, E. (1996). Journal of Clinical Investigation. Vol.98, pp. 2094-2099.

Patlak, C.S. \& Blasberg R.G. (1985). Journal of Cerebral Blood Flow and Metabolism. Vol.5, No.4 (December), pp. 584-590.

Pencek, R.R.; Bertoldo, A.; Price, J.; Kelley, C.; Cobelli, C. \& Kelley, D.E. (2006). American Journal of Physiology: Endocrinology and Metabolism Vol.290, pp. E1124-E1130.

Pendergrass, M.; Bertoldo, A.; Bonadonna, R.; Nucci, G.; Mandarino, L.; Cobelli, C. \& DeFronzo, R.A. (2007). American Journal of Physiology: Endocrinology and Metabolism. Vol.292, pp. E92-E100.

Perret, P.; Ghezzi, C.; Mathieu, J.P.; Morin, C. \& Fagret, D. (2003). Diabetes/Metabolism Research and Reviews. Vol.19, pp. 306-312.

Perret, P.; Slimani, L.; Briat, A.; Ghezzi, C.; Villemain, D.; Halimi, S.; Demongeot, J. \& Fagret, D. (2007). European Journal of Nuclear Medicine and Molecular Imaging. Vol.34, pp. 734-744. 
Petersen, H.A.; Fueger, P.T.; Bracy, D.P.; Wasserman, D.H. \& Halseth, A.E. (2003). American Journal of Physiology: Endocrinology and Metabolism. Vol.284, No. 3 (March), pp. E541548.

Phelps, M.E.; Hoffman, E.J.; Selin, C.; Huang, S.C.; Robinson, G.; MacDonald, N.; Schelbert, H. \& Kuhl, D.E. (1978). Journal of Nuclear Medicine. Vol.19, pp. 1311-1319.

Reaven, G.M. (1988). Diabetes. Vol. 37, pp. 1595-1607.

Rossetti, L.; Stenbit, A.E.; Chen, W.; Hu, M.; Barzilai, N.; Katz E.B. \& Charron M.J. (1997). Journal of Clinical Investigation. Vol.100, pp. 1831-1839.

Samuel, V.T.; Petersen, K.F. \& Shulman, G.I. (2010). Lancet. June Vol.26, Vol.375, No.9733 (June), pp. 2267-2277.

Selberg, O.; Burchert, W.; vd Hoff, J.; Meyer, G.J.; Hundeshagen, H.; Radoch, E.; Balks, H.J. \& Müller, M.J. (1993). Journal of Clinical Investigation. Vol.91, No.5 (May), pp. 18971902.

Sharp, T.L.; Dence, C.S.; Engelbach, J.A.; Herrero, P.; Gropler, R.J. \& Welch, M.J. (2005). Nuclear Medicine and Biology. Vol.32, pp. 875-884.

Shoghi, K.I.; Gropler, R.J.; Sharp, T.; Herrero, P.; Fettig, N.; Su, Y.; Mitra, M.S.; Kovacs, A.; Finck, B.N. \& Welch, M.J. (2008). Journal of Nuclear Medicine. Vol.49, pp. 1320-1327.

Shoghi, K.I. \& Welch, M.J. (2007). Nuclear Medicine and Biology. Vol.34, pp. 989-994.

Slimani, L.; Perret, P.; Briat, A.; Villemain, D.; Ghezzi, C.; Fagret, D. \& Demongeot, J. (2002). CR Biol. Vol.325, No.4, pp. 529-546.

Slimani, L., Oikonen, V., Hällsten, K., Savisto, N., Knuuti, J., Nuutila, P. \& Iozzo, P. (2006). Journal of Clinical Endocrinology and Metabolism. Vol.91, pp. 3394-3403.

Sokoloff, L.; Reivich, M.; Kennedy, C.; Des Rosiers, M.H.; Patlak, C.S.; Pettigrew, K.D.; Sakurada, O. \& Shinohara, M. (1977). Journal of Neurochemistry. Vol.28, No.5 (May), pp. 897-916.

Taylor, S.I.; Accili, D. \& Imai, Y. (1994). Diabetes. Vol. 43, pp. 735-740.

Virtanen, K.A.; Peltoniemi, P.; Marjamaki, P.; Asola, M.; Strindberg, L.; Parkkola, R.; Huupponen, R.; Knuuti, J.; Lonnroth, P. \& Nuutila, P. (2001). Diabetologia. Vol.44, No.12 (December), pp. 2171-2179.

Voipio-Pulkki, L.-M.; Nuutila, P.; Knuuti, M.J.; Ruotsalainen, U.; Haaparanta, M.; Teras, M.; Wegelius, U. \& Koivisto, V.A. (1993). Journal of Nuclear Medicine. Vol.34, 2064-2067.

Vom Dahl, J.; Herman, W.H.; Hicks, R.J.; Ortiz-Alonso, F.J.; Lee, K.S.; Allman, K.C.; Wolfe, E.R.Jr.; Kalff, V. \& Schwaiger, M. 1993. Circulation. Vol.88, No.2 (August), pp. 395404.

Vyska, K, Magloire, J, Freundlieb, C, Hock, A, Becker, V, Schmid, A, Feinendegen, L, Kloster, G, Stocklin, G, Schuier, F 1985 Eur J Nucl Med 11:97-106

Wassenaar, W \& Tator, C.H. (1973). Transactions of the American Neurological Association. Vol.98, pp. 43-48.

Welch, M.J.; Lewis, J.S.; Kim, J.; Sharp, T.L.; Dence, C.S.; Gropler, R.J. \& Herrero, P. (2006). Journal of Nuclear Medicine. Vol.47, pp. 689-697.

Williams, K.V.; Bertoldo, A.; Mattioni, B.; Price, J.C.; Cobelli, C. \& Kelley, D.E. (2003). Journal of Clinical Endocrinology and Metabolism. Vol.88, No.3, pp. 1271-1279.

Yokoyama, I.; Ohtake, T.; Momomura, S.; Yonekura, K.; Yamada, N.; Nishikawa, J.; Sasaki, Y. \& Omata. (1998). Journal of Nuclear Medicine. Vol.39, pp. 884-889.

Yokoyama, I.; Yonekura, K.; Moritan, T.; Tateno, M.; Momose, T.; Ohtomo, K.; Inoue, Y. \& Nagai, R. (2001). Journal of Nuclear Medicine. Vol.42, No.7 (July), pp. 1005-1010.

Yokoyama, I.; Inoue, Y.; Moritan, T.; Ohtomo, K. \& Nagai, R. (2003). Journal of Nuclear Medicine Vol.44, No.10 (October), pp. 1592-1598. 


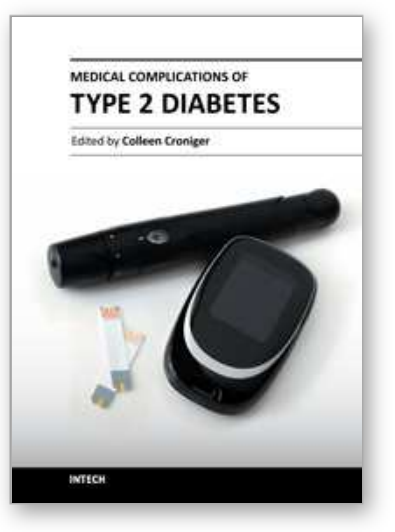

\author{
Medical Complications of Type 2 Diabetes \\ Edited by Dr. Colleen Croniger
}

ISBN 978-953-307-363-7

Hard cover, 412 pages

Publisher InTech

Published online 12, September, 2011

Published in print edition September, 2011

Obesity and type 2 diabetes are increasing worldwide problems. In this book we reviewed insulin secretion in both healthy individuals and in patients with type 2 diabetes. Because of the risk associated with progression from insulin resistance to diabetes and cardiovascular complications increases along a continuum, we included several chapters on the damage of endothelial cells in type 2 diabetes and genetic influences on endothelial cell dysfunction. Cardiovascular complications occur at a much lower glucose levels, thus a review on the oral glucose tolerance test compared to other methods was included. The medical conditions associated with type 2 diabetes such as pancreatic cancer, sarcopenia and sleep disordered breathing with diabetes were also discussed. The book concludes with several chapters on the treatments for this disease offering us hope in prevention and successful alleviation of the co-morbidities associated with obesity and type 2 diabetes.

\title{
How to reference
}

In order to correctly reference this scholarly work, feel free to copy and paste the following:

P. Perret, M. Henri, L. Slimani, D.Fagret and C. Ghezzi (2011). Nuclear Imaging of Glucose

Transport/Metabolism - An Interesting Tool to Screen Insulin Resistance, Refine Diagnosis of Type 2

Diabetes, Understand Disease Mechanisms, and/or Evaluate New Therapies, Medical Complications of Type 2 Diabetes, Dr. Colleen Croniger (Ed.), ISBN: 978-953-307-363-7, InTech, Available from:

http://www.intechopen.com/books/medical-complications-of-type-2-diabetes/nuclear-imaging-of-glucosetransport-metabolism-an-interesting-tool-to-screen-insulin-resistance-ref

\section{INTECH}

open science | open minds

\section{InTech Europe}

University Campus STeP Ri

Slavka Krautzeka 83/A

51000 Rijeka, Croatia

Phone: +385 (51) 770447

Fax: +385 (51) 686166

www.intechopen.com

\section{InTech China}

Unit 405, Office Block, Hotel Equatorial Shanghai

No.65, Yan An Road (West), Shanghai, 200040, China

中国上海市延安西路65号上海国际贵都大饭店办公楼405单元

Phone: +86-21-62489820

Fax: +86-21-62489821 
(C) 2011 The Author(s). Licensee IntechOpen. This chapter is distributed under the terms of the Creative Commons Attribution-NonCommercialShareAlike-3.0 License, which permits use, distribution and reproduction for non-commercial purposes, provided the original is properly cited and derivative works building on this content are distributed under the same license. 